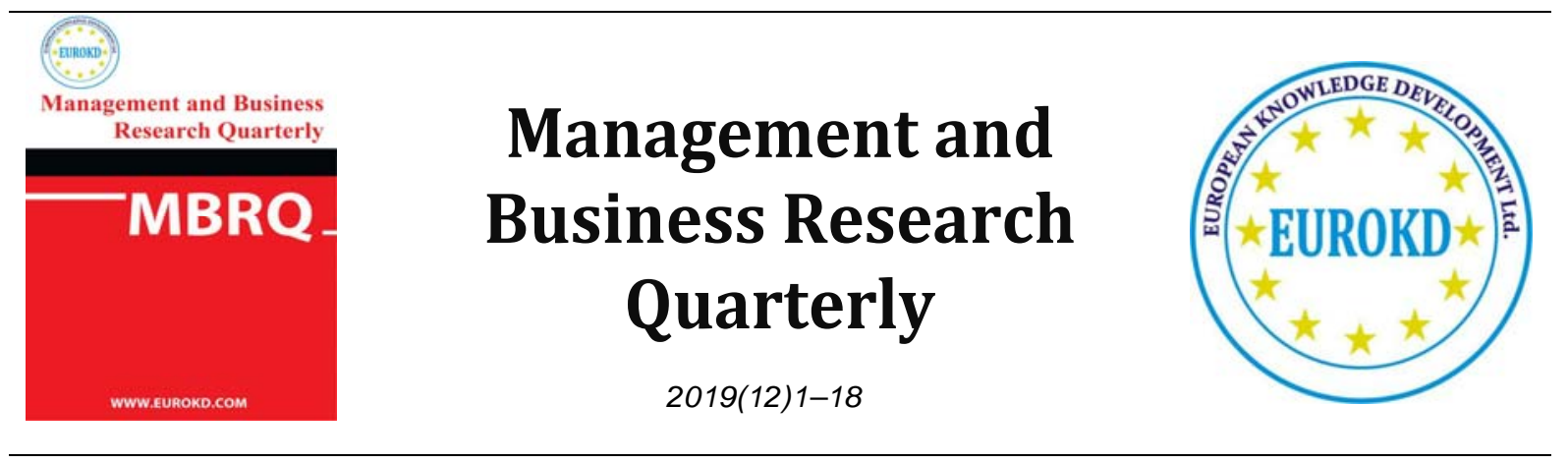

\title{
Utilization of TOPSIS Approach to Formulate Strategy in IRANOL Oil Company
}

\author{
Amirhossein Tayebi Abolhasani ${ }^{1}$, Shahin Rouhani $\operatorname{Rad}^{2, *}$ \\ ${ }^{1} \mathrm{PhD}$. Student of Business Management, Allameh Tabataba'i University in Tehran, Iran \\ ${ }^{2} \mathrm{PhD}$ Student of Business Management, Yazd University in Yazd, Iran
}

Received 17 June 2019 Accepted 26 November 2019

\begin{abstract}
Energy is a strategic commodity that its supply and security plays a critical role in international security and the global economy. Considering Iran's place among the countries active in production of oil and its related industries, identification of strategies related to this sector is of significant importance. At the present time, lubricants industry has become an imperative part of the development of machinery industry and its related industries. This industry has a unique quality and attractiveness when its total number of manufactured products and their markets are considered. Therefore, gaining competitive advantage is of significant importance to the players of this industry. The purpose of this research is to develop strategies for IRANOL Oil Company which is an active and important player in the lubricants industry in Iran. This study is an applied research which utilizes both descriptive and analytical approaches. By using field study method, the lubricants sector was analyzed. Then, by utilizing SWOT matrix, external and internal factors and strategies were identified and then defined through IE matrix. At last, the factors were prioritized based on TOPSIS method. Based on the results, conservative strategy, meaning the 11 strategies in the WO section, were selected for further evaluation and prioritization Which in order of 3 priority are:'strengthening the R\&D department', 'designing and implementing comprehensive marketing strategies incorporating appropriate lateral services by developing sales engineering offices' and 'utilizing the company's full advertising power'.
\end{abstract}

Keywords: Strategic Management, Strategic Planning, SWOT matrix; TOPSIS, IRANOL Oil Company 


\section{Introduction}

In recent years, for many reasons caused managers to realize insightfully that planning in the traditional form will not be able to solve their problems. Hence, the use of strategic planning have been proposed as a necessity in governments, organizations and communities (Bryson, 2011). In other words, todays planners have concluded that given the dramatic changes and accelerated world cannot be expected with a fairly long program successfully (Prezelj, 2015); because the factors contributing to the success of the program are possibly changing and unstable (Grant, 2003). Therefore, strategic planning turned to appear to determine the desired horizons of your organizations and determine how to achieve those goals; Develop operational plans, and continuously get feedback from the realization of small targets that ultimately will fulfill the large vision goals (Haynes, 2005).

Given the role of oil in community economic development, the strategic management of subsets of this area is very important (Tavana, Pirdashti, Kennedy, Belaud, \& Behzadian, 2012). But it should not be forgotten that we should not follow the general steps 1,2 and 3, in management. And despite some general remarks and shared between organizations, every organization and company, are qualified to fit himself with other organizations and their strategies will be different from others (Shojaei, 2015).

According to the Iran document of future perspective in 2025, and achieving the first place in economy, science and technology in Southwest Asia including Central Asia, Caucasus, the Middle East and neighboring countries, the role of value-added petroleum products is very important (Shojaei \& Siayhpoush, 2011) and it is one of the important area to achieve this goal and the development of the country's lubricant industry.

Also, lubrication science is known as one of the most important disciplines in science and engineering, So that the success of many industrial projects will be dependent on this technical knowledge. In general, lubricants and additives cause to increase the oil longevity and quality, and now due to environmental issues are very important (Shekarriz, AliAkbari, \& Pourrezaye, 2014). In other words, today the lubricant industry has become an important part of the development of modern industries and other industries related to it. In addition, by applying new issues such as saving and preserving non-renewable resources as well as compliance with environmental requirements, lubricants study has found a special place in science (Hajmohammadi, 2017). Another important issue is the lack of attention to strategic planning principles in the country's lubricant industry, which may be innovation of this new area of research from the lubricant industry companies, which so far there has been paid less attention.

\section{Theoretical principles}

From the perspective of social sciences and in particular management, scholars have provided different definitions for the word "strategy" in this field (Guerras-Martín, Madhok, \& MontoroSánchez, 2014). A fairly comprehensive divisions on the definition of this term is the five strategies classification from the Mintzberg's perspective. Mintzberg define the strategy as a plan, craft, pattern, position and attitude (Ebrahimi \& Tabatabai, 2000). In other words, strategies are the tools that companies can thereby achieve their goals. Also, strategic management is defined as "a set of 
analysis, decision-making and operations in order to create and sustain a competitive advantage for a company" (Dess, Lumpkin, \& Taylor, 2004). Also, "Strategic management is introduced as a set of decisions and actions that lead to the formulation and implementation of scheduled plans to achieve the corporate objectives" (Pearce and Robinson, 2004). According to academic definitions mentioned above, where the terms of competition, creation and maintenance the competitive advantages and also achieving development goals are outlined as main concepts; it can be said that the main theme of the strategic science is competitive (Guerras-Martín et al., 2014).

In the meantime, the stage of strategy formulation in strategic management is called strategic planning. The term "strategic planning" was used mainly in the early 1970s, and a group of experts tried to introduce it to the managers and organizations decision-makers (Grant, 2003). Strategic planning is a process that the organization's leaders, predict its future due to changing conditions, and develop necessary methods and procedures to achieve its objectives (Goodstein, Nolan, \& Pfeiffer, 1992).

In the 1990s, it was a very different perspective and different classifications arose for strategic planning (Coman \& Ronen, 2009). A common classification is classified into two categories: short term and long term (Glaister \& Falshaw, 1999). Another classification is 3 styles of Mintzberg strategic planning. These three styles are developed plans, which fits with the predictable environment; Entrepreneurial plan, which fits with predictable and unpredictable environment and the third style with the progress of science by distress that has risky style and fits with unpredictable environments (Mintzberg, 1994).

Also, a variety of strategic planning models, like the David model in 1994, the Hill model in 1992, the Goodstein and colleagues model in 1992, Bryson model was created in 2011, which of course we are not going to deal with it (David, 2011; Hill, Jones, \& Schilling, 2014; Goodstein et al., 1992; Bryson, 2011).

But in a more general view, we can say that the overall process involves identifying and analyzing strategic planning, development, implementation, and finally examine the consequences on the environment. That among them, according to two goals, determining the competitive realm and also determining the competitive advantages is very important (Hajipour, 2015). Also, it can be said that one of the basic principles of this type of planning is that organizations need to take advantage of opportunities and avoid the effects of threats or reduce them in order to cope with strategies formulations (Phadermrod, Crowder, and Wills, 2016). And on the other hand, one of the essential activities in this time is to identify and assess the strengths and weaknesses of departments and units of the organization (Pearce \& Robinson, 2004).

\section{TOPSIS technique}

Multi Criteria Decision Making has developed quickly decade due to various functional requirements during the last. This technique is accepted in all areas of decision-making (Saaty, Hatami marbini, \& Nakoie, 2007). Multi-criteria decision-making process is selecting an option from the available options (Biorani \& Ghofran, 2009). Meanwhile, the multi-criteria decision- 
making models are divided into two groups: multi-objective decision-making model and Multiple Attribute Decision Making model.

In general, multi-objective model is used to design and multi-attribute model is used for the preferred option. In other words, multi-objective models, are used when the options are almost unlimited and uncertain, and are mostly used for the initial design and planning. But multi-attribute model are used when the options are specified and limited and they are mostly used for evaluation and selection (Ghazinoory, 2005).

In the meantime, many models have been proposed for multi-criteria decision-making each with specific characteristics. One of the techniques that are used to rank factors, is the TOPSIS model. This technique is including the methods of compensation in MADM that receives the sum of the weights of the decision maker (Mehregan \& Dehghannayeri, 2009).

TOPSIS technique or preferred methods, based on similarity to ideal solution, that first introduced in 1981 by Huang and ions, is one of the multi-criteria decision-making methods (MCDM) and a type of Multiple Attribute Decision Making (MADM) (HajiNejad, Taghizadeh, \& Rahimi, 2014 ). This technique can be used to rank and compare different options and choose the best option and determine the spacing between options and their grouping. Among the advantages of this method is that the criterion or criteria used for comparison can have different units of measure and have a positive and negative nature. In other words, we can use the positive and negative characteristics in compound form in this technique (Momeni, 2006). Based on this method, the best option or solution is the closest solution to ideal solution, or the farthest solution from the non-ideal solution. Ideal solution is a solution that will have maximum benefit and minimum cost and in short, achieved from the sum of the maximum values for each criterion. Problem solving by this method requires the following six steps that have been used in this research.

- 1. To quantify and descale of decision matrix contains $m$ option and $n$ criteria $(\mathrm{N})$ : for descaling, norm descaling is used.

- 2. To obtain descaled weighted matrix $(\mathrm{V})$ : descaled matrix $(\mathrm{N})$ is multiplied in weighted diagonal matrix (Wnxn), it means:

Wnxn $\mathrm{V}=\mathrm{N} *$

- 3. Determining the positive ideal solution $(\mathrm{V} \mathrm{j}+)$ and negative ideal solution $(\mathrm{V} \mathrm{j}-)$ :

- 4. To obtain distance from each option to positive and negative ideals:

Euclidean distance from each option to a positive ideal

$$
, \mathrm{i}=1,2, \ldots, \mathrm{m} \quad \mathrm{d}_{\mathrm{i}}^{+}=\sqrt{\sum_{j=1}^{n}(v i j-(v j+))^{2}}
$$

Euclidean distance from each option to an ideal negative

$$
, \mathrm{i}=1,2, \ldots, \mathrm{m} \quad \mathrm{d}_{\mathrm{i}}{ }^{-}=\sqrt{\sum_{j=1}^{n}(v i j-(v j-))^{\wedge} 2}
$$

- 5. To determine the relative proximity $(\mathrm{CL} *)$ to an option, ideal solution:

$$
C L i *=\frac{d i-}{(d i-)+(d i+)}
$$


6. Rankings Options: Each option that its $\mathrm{CL}^{*}$ is bigger, is better (Sheng-Hshiung, 2002).

\section{Lubricants industry}

As noted, lubrication is the knowledge of simple relative motions of the level in contact with each other (Panda, Jayashree, and Pandey, 2017). This science is known as one of the very important disciplines in science and engineering, so the success of many industrial projects will be dependent on knowledge of technical knowledge (Hasannuddin et al., 2016). In general, the layers of gas, liquid or solid that fall between the two levels and improve the motion uniformity up a level on the other and prevent from damaging on surfaces, is said lubrication (Amani Dolatsara, 2005). Today, the lubricant industry has become an important part of the development of modern industries, and the related industries. Moreover, by raising new issues such as consumption optimizations and preserving non-renewable resources and compliance with environmental requirements, a study on lubricants, has found a special place in science (Shahidipour, 2005). While the by 2020, the demand for lubricating oil in China will have doubled, and consumption will surpass America (Report on China Lubricating Oil Market, 2011-2015).

Lubricants in a general view, can be divided into two broad categories as automotive and industrial lubricants. Also, Industrial lubricants are divided into two other main group of industrial oils and special lubricants such as greases, metalworking lubricants and solid lubricants. Of course, lubricants can be classified in terms of physical modes (four gas lubrication, fluids state lubrication, grease and solid state lubrication) (Garvey, 2000) lubricants have important applications in internal combustion engines, vehicles, industrial gears wheels, compressors, turbines, hydraulic systems, etc. $90 \%$ of consumption lubricants are comprised of lubricating oils, that among them automotive oils have the highest consumption, and therefore attention to the automotive market is very important (Gosalia, 2014).

Growth in the global automotive industry in recent years has increased demand for lubricants, however, due to the world stagnation of 2008-2009, the car sales has declined which also would be difficult to sell lubricants. In this period of stagnation, the growth of the automotive industry in the Asia Pacific region, particularly in India and China, partly support the lubricants market. These countries have the world's highest economic growth and their GDP growth rate is higher than the global growth rate (Gosalia, 2014). In the meantime, China has the largest auto market in the world and America is in second place. Lubricants market in North America and Europe is relatively mature and has strict rules that require the use of oils Group 2 and 3. However, it is expected that price volatility of lubricants, resulting from the continuous fluctuations in the market price of crude oil remains a key factor in the market. In order to mitigate these effects, global industry has focused on the development synthetic lubricants and the lubricants based on vegetable oils. This oil, in addition to having much more economical saving than conventional oils, tolerate higher temperature for consumers.

Also, now there are more than 1700 lubricant manufacturer in the world that about 200 companies for lubricant production side and the production side, and about 1500 companies paid specifically to produce lubricants. More than $60 \%$ of consumption lubricants in the world produce 
by less than $2 \%$ of these companies, which went on to become more familiar with it (Abolhasani, Rouhani Rad, \& Tahouryan, 2015). The share of each of the products of the production, it can be said, as can be seen in the following figure, automobile oil group with a share of 56 percent of the total production of lubricants accounted for the largest share in 2013 and the next rank is industrial oils with a share of 26 percent. In the figure, the share of motor oil has been shown by segregating in the areas (Gosalia, 2014).

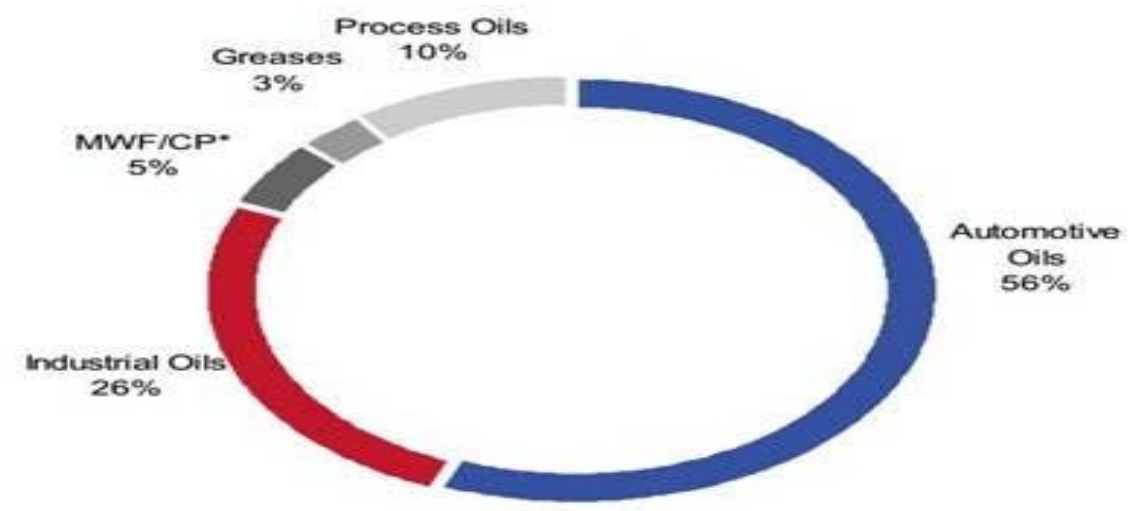

Figure 1: Separation of lubricants production categories in the world (Gosalia, 2014)

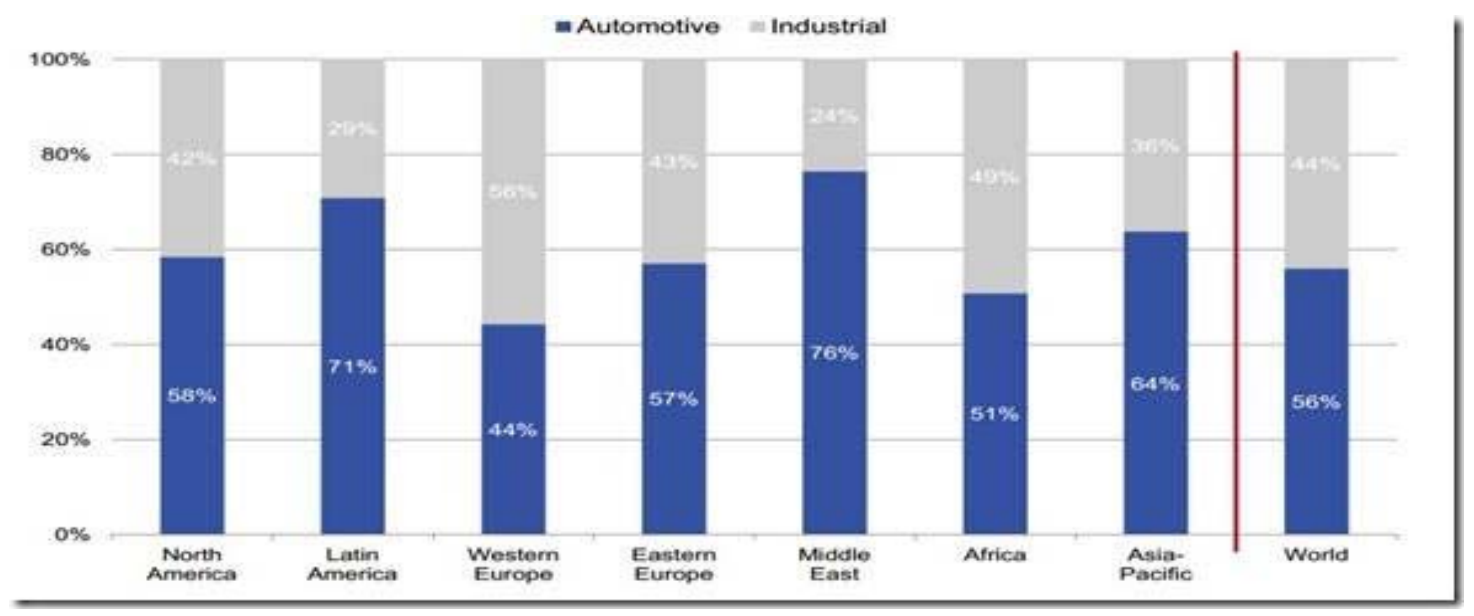

Figure 2: The share of manufactured products for different regions (Gosalia, 2014)

As seen in the figure below, China is the world's largest producer of lubricant. Iran is ranked as tenth in the largest lubricant manufacturers in the world in 2013 (Gosalia, 2014). 


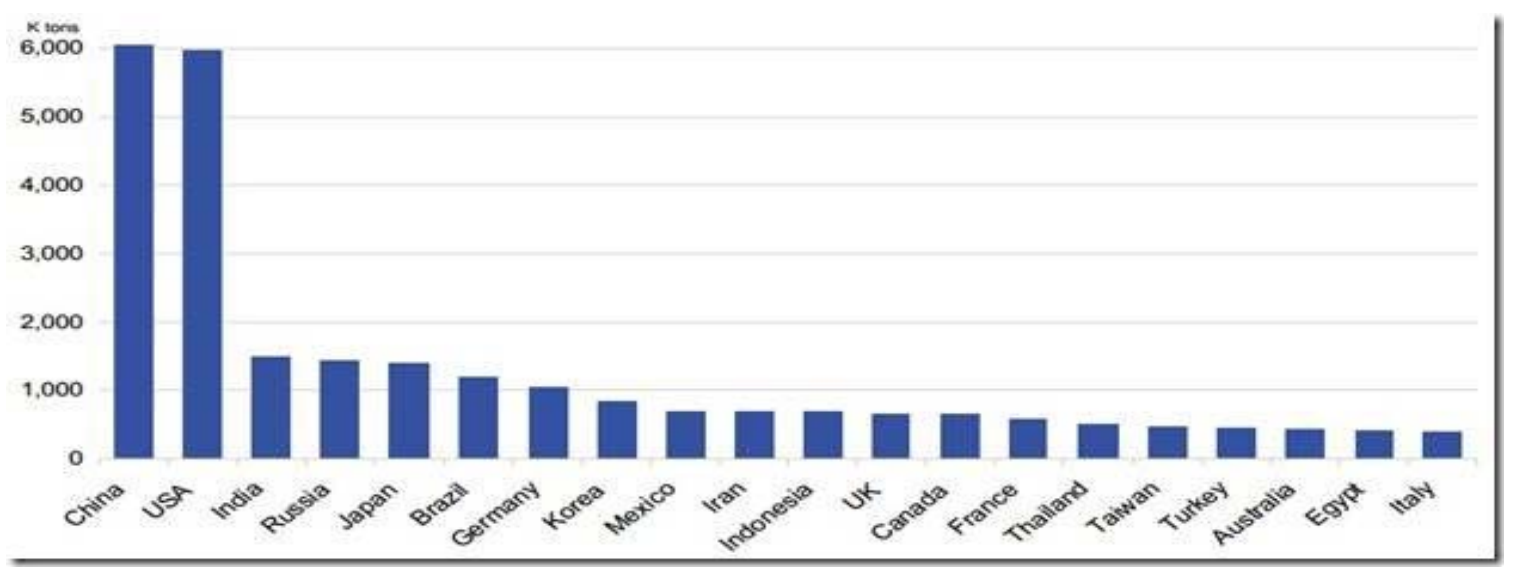

Figure 3: Ranking 20 top lubricant manufacturers in the world (Gosalia, 2014)

In Iran, the engine oil as a strategic commodity has a significant impact on continuity and dynamism of freight and transport fleet and the inside and outside urban passengers. According to figures provided by consumer and manufacturers protection agencies, a significant part of the needs of the country (about 85 percent) of engine oils is provided by four large companies in the country (BEHRAN with 42,5 percent, IRANOL with 17 percent, PARS with 14.5 percent, SEPAHAN with 11 percent) (Consumer and manufacturers protection organizations, 2015).

\section{Research background}

Despite the studies conducted, unfortunately strategic issues in the lubricant industry, very little research was found, so we point out to some similar studies. Jiang and his colleagues in a research paid to study SWOT-AHP hybrid model for vehicle lubricants from CNPCLC, China. In this paper, by using the analytic hierarchy process technique that has the advantage of combining quantitative with qualitative analysis, a SWOT-AHP model for CNPCLC vehicle lubricants is developed, presenting a good tool for studying the competitive factors domestic and overseas for vehicle lubricants. Finally a strategic plan for CNPCLC vehicle lubricants is suggested (Jiang, Xu, \& Xin, 2012).

Ramírez-Cendrero and Paz in a research paid to study oil fiscal regimes and national oil companies: A comparison between Pemex and Petrobras. They compare investment, production, and reserve indicators of Pemex and Petrobras and conclude that the Mexican and Brazilian oil fiscal regimes can largely explain the productive and investor performance of both NOCs (RamírezCendrero \& Paz, 2017).

Else researcher published paper about Genetic algorithms in oil industry. His model presented cover specific aspects of application in reservoir characterization; nevertheless applications in other aspects are shown. The results are directed to improve the satisfaction by the performance of the methods of simulation of those properties in the reservoir characterization that have impact in the petroleum production (Velez-Langs, 2005). 
Also Ermida paid to strategic decisions of international oil companies (Ermida, 2014). Ravandi and his colleagues in a research study referred to combination of fuzzy logic and genetic algorithm in Reservoir characterization (Ravandi, Nezamabadi-Pour, Monfared, \& Jaafarpour, 2014).

In Iran refer to article below. Mahmoudi and his colleagues in his book called "Strategic Management in Oil, Gas, Refining and Petrochemicals", paid to explain and describe the concepts, models and approaches to strategic management and examined the benefits as well as defining strategies, organization, business and functional and the prospects, mission, core values and organizational goals with an emphasis on oil, gas, refining and petrochemical, and also studied outlines of a variety of strategies, best practices and operational strategy, and strategic infrastructure requirements and discussed implementation and strategic control systems and assessment strategies (Mahmoudi, Surrey, \& Tajrish, 2014).

Yadghar and Tahmasebi in a research paid to study strategic marketing management about oil, gas and petrochemical, Case Study, marketing and strategic planning model in GC companies in Iran. This article is provided in four categories, including the problem type (the problems of oil and gas projects, etc.), research literature (the concepts related to project management, GC, the implementation of upstream projects, global markets, etc.), case study, the proposed model (features of the proposed administrative structure and model ...) and results (benefits of the proposed model based on standards of project management, administrative requirements, the results obtained from the proposed model, etc) (Yadghar \& Tahmasebi, 2007).

Mohammadpour, in an article paid on investment strategies for investing in the upstream sector of the Iran oil industry. The results showed that the weighted basket of formulated strategies is as 0.44 percent for invasive strategy, 0.20 percent for defensive strategies, 0.19 percent for competitive strategy and 0.17 percent for shift strategy. And the last is aggressive selected strategy or SO, with $0.44 \%$ relative to other strategies that it is advisable to develop the upstream sector of the Iran oil industry (Mohammadpour, 2016).

Bakhtiari and his colleagues in a research study the dynamics of their strategic industrial lubricants. In this study, by using a dynamic approach and dynamic analysis tools, it is paid to examine how the selection of strategic issues in order to provide the necessary context for the review of the lubricants production strategy. In this regard, dynamics analysis was conducted on strategic issues, so that to identify the roots and the main factors influencing the strategic issues of the organization. To classification analysis, a Porter's value chain framework was used. Root causes, mediating variables and variables in different areas of the organization was identified with a squeal navigation view, and then each of these elements position were determined in Porter's value chain. Finally, the number and weight of the root causes of organizational strategic issues were prioritizing by using hierarchical AHP that organization can focus more on strategic selection by a higher priority (Bakhtiari, Vazir Zanjani, \& Becker, 2014).

Also, Safaye in an article paid to identify and prioritize critical success factors in the Iran lubricants industry by using ANP (with the approach of competitive advantage). Based on the approved agents of Thompson and Strickland models and expert opinion, a questionnaire based on ANP methods was prepared and presented to industry experts. Finally, five factors of the 
"experience in product innovation", "technical knowledge", "quality", "access to raw materials and additives" and "access to skilled labor" were identified as critical success factors in this industry (Safaye, 2013).

\section{Research Methodology}

The main purpose of this research is to develop large strategies for IRANOL Oil Company, that the present analytical model was designed based on three phase input models, SWOT and David analytical framework to compare and make decisions (David, 2011). In leading research, after identify and default the mission, vision and long-term goals of IRANOL Oil Company, the following three stages of analytical models were followed respectively.

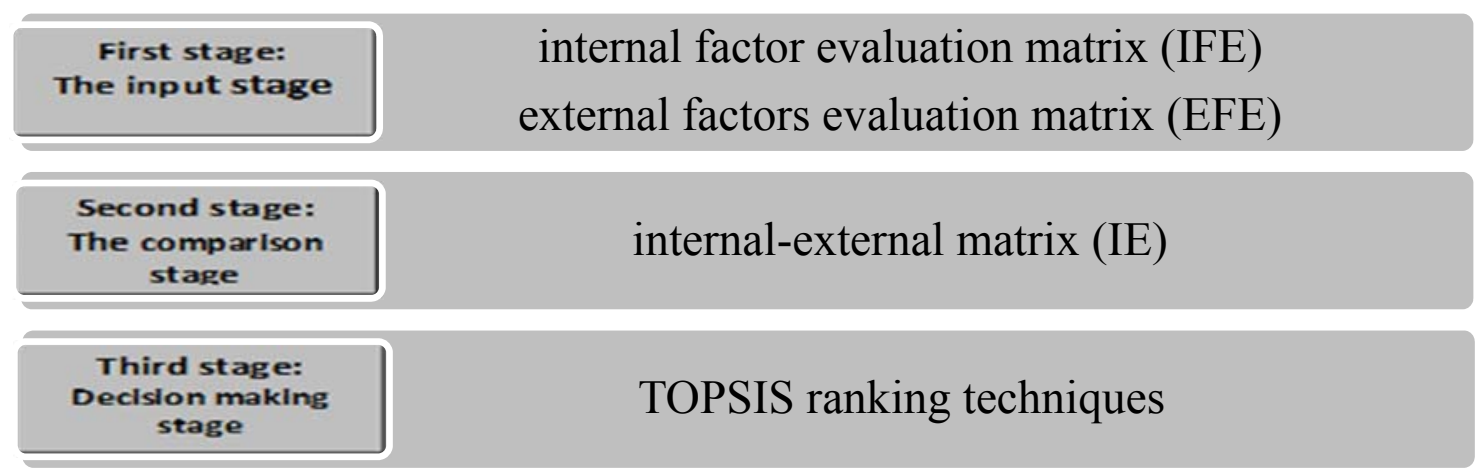

Figure 4: analytical model

This is an applied research and by the nature is descriptive analysis, and it is in relation to the IRANOL oil company and its data, and has been investigated in the period of the beginning of 2015 until the beginning of 2016. In order to achieve the research objectives, the following actions were done:

- Performing the primary library studies, and then study the documents of the enterprises and upstream to identify and articulate the issues such as mission, vision and organizational goals.

- To Study the external and internal organizational environment in order to identify the strengths and weaknesses of the organization, as well as the opportunities and threats to the organization, through interviews and questionnaires.

- In the next stage, this research that is devoted to field research, weight and feed components through questionnaires and interviews with managers, experts, customers (switching lubricants and repair (Auto services), sales agents and dealers, drivers) and the related authorities involved were collected in this area, and its validity and reliability was approved. The results obtained after analyzing the IFE and EFE tables, were analyzed by the SWOT analysis, and by using internal and external matrix (IE) major strategies for the organization were developed and in the end, large strategies were ranked by using the experts view and TOPSIS method.

Here, for better understanding of the organization under study, the information about it is presented. National Iranian Oil Company in line with the privatization of public companies,_has assigned_Oil units of refineries in Tehran and Abadan to Social security organizations,_State pension fund and 
Astan Quds Razavi that this disposal resulted in the establishment of IRANOL Oil Company on 11 December 2003. Oil units of refineries in Tehran and Abadan, after separating from the body of the National Iranian Oil Company, are working by the name of oil unit refineries in Tehran and Abadan from IRANOL Oil Company. Oil units of refineries in Tehran along with oil units of refineries in Abadan, with a total production of more than $30 \%$ basic oil of the country in the year, are the dominant force in the lubricants market.

IRANOL Oil Company by production, supply and trade all kinds of oils, industrial and automotive lubricants, Oil derivatives and participation in related beneficial businesses, take action in order to serve the interests of stakeholders. That its perspective is to be perfect in the lubrication industry in the Middle east that will be achieved by relying on strength in the production of oil and diversification on specialty products.

IRANOL Oil Company consists of five sets of oil refinery in Tehran, oil refinery in Abadan, collection of containers and packaging in Tehran, Ehya Sepahan lubricants company, integrated production and packaging in Esfahan. It should be noted that the company's products divide into 8 gasoline engine oils, diesel engine oils, motorcycle oils, natural gas engine oils, gear oils, antifreezeanti boil, industrial oils and process, and in general it has about 72 products with different grades and for different purposes.

\section{Results and data analysis}

The findings related to results of internal and external factors evaluation matrix, SWOT matrix and prioritize TOPSIS are provided below.

\section{Internal factors evaluation matrix (IFE)}

In this matrix, after the major internal factors determined, the selected strengths and weaknesses were given the zero weight (insignificant) to one (very important), So that the sum of the weights, equals the number one. Weight represents that company compliance with its operators that is used to identify strengths weight, basis of comparison, and our distance with the top competitors, and also to determine weak weight, basis for comparison, our distance with the low competitors (Shojaei, 2015).

Then, each of the strengths and weaknesses identified, are given importance coefficient which reflects the impact of that factor on the examined industry. Then, by multiplying the weight in coefficient of importance, points or the final score is obtained, that by using them the sum of the numeric scores is determined ranging from 0 to 4 and averaged 2.5, If the total score is more than 2.5 , which means the advantage of strengths than weaknesses, and if the score is less than 2.5 it means it has overcome the weaknesses on strengths (Shojaei, 2015). 
Table 1: internal factors evaluation matrix (IFE) for IRANOL Oil Company

\begin{tabular}{|c|c|c|c|c|}
\hline row & Description of factors & weight & $\begin{array}{l}\text { importance } \\
\text { coefficient }\end{array}$ & score* \\
\hline \multicolumn{5}{|c|}{ strengths } \\
\hline S1 & Strong marketing department with coherent and systematic programs & 0.04 & 4 & 0.17 \\
\hline S2 & Active participation in international exhibitions & 0.04 & 4 & 0.16 \\
\hline S3 & $\begin{array}{l}\text { Extensive advertising in auto service centers (principally in the entrance } \\
\text { panel, promotional clothing, posters and stand) }\end{array}$ & 0.04 & 3 & 0.13 \\
\hline$S 4$ & Lower transport costs of raw materials of Lübeckat, and vacuum baton & 0.05 & 4 & 0.22 \\
\hline S5 & Optimization of the company's sales portfolio & 0.05 & 3 & 0.15 \\
\hline$S 6$ & High satisfaction of employees due to new management & 0.05 & 2 & 0.11 \\
\hline$S 7$ & the company brand acceptance & 0.03 & 2 & 0.06 \\
\hline$S 8$ & confirmations, and valid Certificates & 0.03 & 3 & 0.09 \\
\hline S9 & Distribution policy on distribution of goods & 0.05 & 2 & 0.10 \\
\hline$S 10$ & Refinery hydrogen purification unit & 0.04 & 3 & 0.12 \\
\hline$S 11$ & $\begin{array}{l}\text { The only company with a complete production line, plastic containers and } \\
\text { packaging, with stylish and innovative packaging products }\end{array}$ & 0.06 & 4 & 0.25 \\
\hline$S 12$ & The company management policies in order to improve staff & 0.04 & 2 & 0.08 \\
\hline$S 13$ & The annual ceremony, with auto service operators and top agents & 0.05 & 3 & 0.14 \\
\hline S14 & Communication systems with sales agents and auto services & 0.05 & 2 & 0.09 \\
\hline$S 15$ & Sales engineering offices & 0.05 & 3 & 0.14 \\
\hline$S 16$ & The ability to export products & 0.03 & 3 & 0.09 \\
\hline \multicolumn{5}{|c|}{ weaknesses } \\
\hline W1 & Conversion of a low base oil to the final product & 0.04 & 1 & 0.04 \\
\hline W2 & Low cart products for new model cars & 0.03 & 2 & 0.06 \\
\hline W3 & $\begin{array}{l}\text { Precise control of the process of maintenance and repair equipment } \\
\text { program }\end{array}$ & 0.04 & 1 & 0.04 \\
\hline W4 & Activities related to after-sales service & 0.04 & 1 & 0.04 \\
\hline W5 & Weakness in the $R \& D$ unit & 0.05 & 1 & 0.05 \\
\hline W6 & Company management changes & 0.05 & 1 & 0.05 \\
\hline W7 & Non-use of all advertising possibilities & 0.04 & 2 & 0.08 \\
\hline Total & & 1 & & 2.46 \\
\hline
\end{tabular}

* Obtained numbers were rounded to two decimal places, and due to this reason some differences have been observed.

\section{External factors evaluation matrix (EFE)}

This matrix is prepared just as internal factors evaluation matrix, is a result of a strategic evaluation of external factors and glance at the strengths and weaknesses within the organization. Weight zero (unimportant) to one (very important) is given, In this case, the sum of the weights is number one. Weight represents the examined company's compliance, by that operator and the effect on it.

Then, each of the opportunities and threats are identified, are given a significance level which reflects the impact of the examined industry. Then, as in previous matrix, points or the final score is obtained by multiplying weight coefficient of importance. By using it, the sum of the numeric scores is determined ranging from 0 to 4 and an average of 2.5, If the total score is more than 2.5, 
it means the superiority of opportunities than threats and if the score is less than 2.5 , it means threads have overcome the opportunities (Shojaei, 2015). After the surveys, eventually 16 opportunities parameter, and 12 threats parameter were identified that the results are presented in the table below.

Table 2: external factors evaluation matrix (EFE) for IRANOL Oil Company

\begin{tabular}{|c|c|c|c|c|}
\hline row & Description of factors & weight & $\begin{array}{l}\text { importance } \\
\text { coefficient }\end{array}$ & score \\
\hline \multicolumn{5}{|c|}{ opportunities } \\
\hline 01 & Increasing the number of vehicles traveling in the country & 0.04 & 4 & 0.16 \\
\hline 02 & Cruel sanctions Cancellation & 0.03 & 4 & 0.13 \\
\hline O3 & The government supporting policies & 0.04 & 3 & 0.12 \\
\hline 04 & $\begin{array}{l}\text { Completion and commissioning of the first and second phase of oil units in } \\
\text { Tehran Refinery }\end{array}$ & 0.04 & 3 & 0.12 \\
\hline O5 & $\begin{array}{l}\text { The beginning of Import and export terminal project of Imam Khomeini } \\
\text { port, by the end of } 2015 \text { in the company }\end{array}$ & 0.04 & 3 & 0.12 \\
\hline 06 & Increasing awareness towards domestic products & 0.04 & 3 & 0.12 \\
\hline 07 & $\begin{array}{l}\text { Using modern methods for the production of vehicle lubricant, in the semi- } \\
\text { synthetic and synthetic level (increased quality) }\end{array}$ & 0.03 & 3 & 0.08 \\
\hline 08 & Production of base oils of Group 2 and 3 & 0.03 & 2 & 0.06 \\
\hline 09 & Expanding products exports & 0.03 & 2 & 0.06 \\
\hline 010 & Increased production for imported cars & 0.04 & 4 & 0.16 \\
\hline 011 & Boost R \& D & 0.04 & 4 & 0.16 \\
\hline 012 & Expanding domestic market & 0.03 & 2 & 0.06 \\
\hline 013 & Formulation and implementation of comprehensive marketing strategies & 0.04 & 2 & 0.07 \\
\hline 014 & Expanding the sales engineering offices & 0.04 & 3 & 0.12 \\
\hline 015 & Development laboratories and technologies to reduce raw material sales & 0.03 & 2 & 0.06 \\
\hline 016 & management stability Policy & 0.03 & 2 & 0.06 \\
\hline \multicolumn{5}{|c|}{ threads } \\
\hline T1 & Changes in government policies in the field of oil and its products & 0.04 & 1 & 0.04 \\
\hline$T 2$ & Intensification of environmental regulations & 0.04 & 2 & 0.08 \\
\hline T3 & External engine oil imports & 0.04 & 1 & 0.04 \\
\hline T4 & Increasing the modern cars imports & 0.04 & 1 & 0.04 \\
\hline T5 & Strict monitoring of the protection of consumers and producers on the price & 0.03 & 4 & 0.11 \\
\hline T6 & Interruption or shortage of electricity and gas in the refineries & 0.03 & 3 & 0.08 \\
\hline$T 7$ & Exchange rate fluctuations & 0.04 & 2 & 0.08 \\
\hline T8 & Entry of new competitors into the market. & 0.04 & 2 & 0.08 \\
\hline T9 & The higher quality of the competitors & 0.04 & 2 & 0.08 \\
\hline T10 & Larger advertising of competitors. & 0.04 & 2 & 0.07 \\
\hline$T 11$ & Laws and regulations in relation to export in this area & 0.03 & 3 & 0.08 \\
\hline T12 & Increasing the oil quality standards & 0.04 & 3 & 0.12 \\
\hline Total & & 1 & & 2.57 \\
\hline
\end{tabular}

* Obtained numbers were rounded to two decimal places, and due to this reason some differences have been observed. 


\section{Internal and external matrix (IE)}

Whistle matrix is one of the most important tools that managers use to compare information, and based on them, they can develop four types of strategies (Ali Ahmadi, Fathallah, and Taj al-Din, 2004). In this matrix, the result of internal factors evaluation matrix (IFE) and external factors evaluation matrix (EFE) are used, and strategic direction of the organization is determined on the SWOT matrix. Matrix IE has four regions aggressive, conservative, defensive competitive, and by using the total scores of the IFE and EFE, the area is selected (Ali Ahmadi et al., 2004).

Number 2,46 obtained from the matrix IFE indicate the dominance of weaknesses on the strengths of the company. Also, the number 2.57 obtained from the matrix EFE represents the dominance of environmental opportunities on environmental threats.

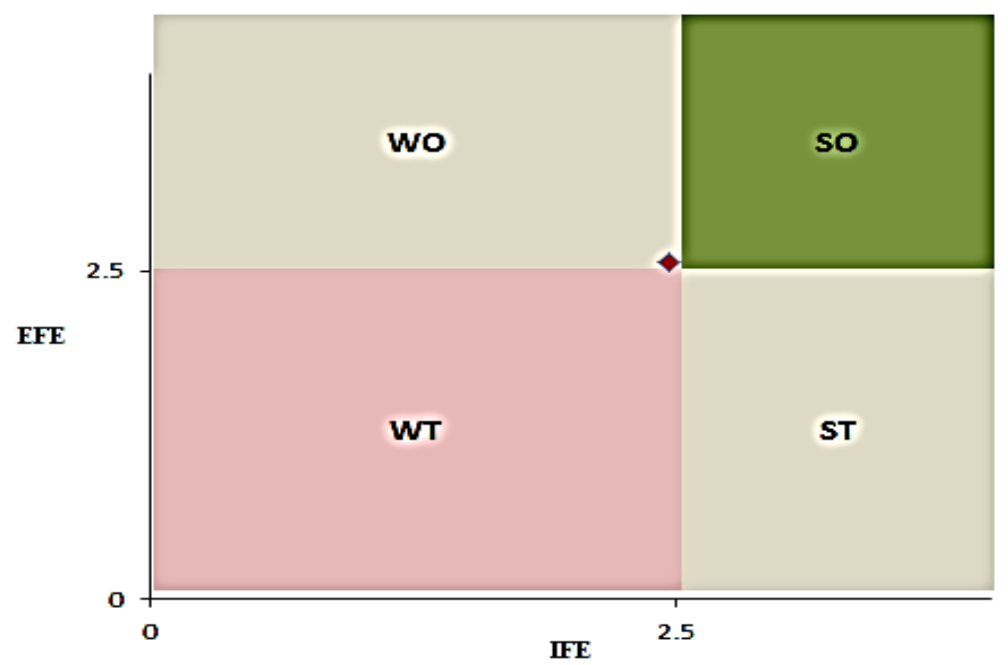

Figure 5: The Ultimate SWOT Matrix of IRANOL oil company

So, the situation of IRANOL Company is in the WO position. Therefore, the company should take advantage of the potential that lies in environmental opportunities to compensate for the weaknesses of the organization; In other words, it takes the conservative strategy by changing some of its activities for the activities foundation.

\section{TOPSIS ranking decision-making technique}

Now, is the final step in the process of developing a strategy and research results, it means the selection of the best strategy among the possible options. Therefore, in order to rank better strategies on the WO areas, TOPSIS technique was used in which they were evaluated by experts according to the 11 strategies identified in the conservative field and six weighted index (in direction of Longterm goals, acceptability, feasibility, cost and benefit study, compliance with laws as well as simplicity (Stacey, 2003; Shojaei, 2005). The final results are presented in the following tables. 
Table 3: the strategies table scoring of WO strategies in the field of IRANOL Oil Company

\begin{tabular}{|c|c|c|c|c|c|c|c|}
\hline $\begin{array}{l}\text { Strategy } \\
\text { number }\end{array}$ & criterion & $\begin{array}{l}\text { Long } \\
\text { term } \\
\text { goals }\end{array}$ & $\begin{array}{l}\text { Accept } \\
\text { ability }\end{array}$ & possibility & $\begin{array}{c}\text { Costs } \\
\text { and } \\
\text { benefits }\end{array}$ & $\begin{array}{c}\text { Compliance } \\
\text { with laws }\end{array}$ & simplicity \\
\hline $\begin{array}{l}1 \\
\mathrm{~W} 1 \mathrm{O} \\
1,3,4,5,8\end{array}$ & $\begin{array}{l}\text { Increasing the conversion of base oil to the finished product, } \\
\text { according to the company's internal development capacities, } \\
\text { policies, government support, and increasing the number of } \\
\text { vehicles traveling in the country }\end{array}$ & 10 & 6 & 6 & 7 & 9 & 5 \\
\hline $\begin{array}{l}2 \\
\mathrm{~W} 109\end{array}$ & Expanding export base oil and finished product & 8 & 8 & 7 & 8 & 9 & 7 \\
\hline $\begin{array}{ll}3 \\
\mathrm{~W} 1 \mathrm{O} 15 \\
\mathrm{~W} 3 \mathrm{O} 15\end{array}$ & $\begin{array}{l}\text { Expanding the labs and technologies to reduce crude sales, } \\
\text { and improve maintenance system and repairing the } \\
\text { company }\end{array}$ & 10 & 8 & 7 & 9 & 9 & 7 \\
\hline $\begin{array}{l}4 \\
\mathrm{~W} 2 \mathrm{O} 4,7,10\end{array}$ & $\begin{array}{l}\text { Increasing the variety of product portfolio for new model } \\
\text { cars according to the company's internal development } \\
\text { capacities and all type of new production methods to } \\
\text { produce synthetic and Semi-synthetic lubricants }\end{array}$ & 10 & 8 & 7 & 9 & 8 & 6 \\
\hline $\begin{array}{l}5 \\
\mathrm{~W} 3 \mathrm{O} 2\end{array}$ & $\begin{array}{l}\text { Precise control of the maintenance process, and repairing } \\
\text { application equipment, according to revoke the unjust } \\
\text { sanctions }\end{array}$ & 7 & 8 & 7 & 9 & 9 & 7 \\
\hline $\begin{array}{l}6 \\
\mathrm{~W} 4 \mathrm{O} 6,12 \\
\end{array}$ & $\begin{array}{l}\text { Improve after-sales service to take more market share } \\
\text { domestically, and attention to people awareness }\end{array}$ & 10 & 7 & 7 & 9 & 8 & 8 \\
\hline $\begin{array}{l}7 \\
\mathrm{~W} 4 \mathrm{O} 12,13, \\
14 \\
\mathrm{~W} 7 \mathrm{O} 12\end{array}$ & $\begin{array}{l}\text { To develop and implement a comprehensive marketing } \\
\text { strategies by additional services and developing sales } \\
\text { engineering offices }\end{array}$ & 10 & 9 & 7 & 9 & 9 & 7 \\
\hline $\begin{array}{l}8 \\
\text { W5O6,7,10 }\end{array}$ & $\begin{array}{l}\text { Pay special attention to the strengthening of } \mathrm{R} \& \mathrm{D} \text {, for } \\
\text { selling higher quality products for new models of imported } \\
\text { cars and attention to the increasing people awareness of the } \\
\text { products }\end{array}$ & 10 & 9 & 8 & 9 & 9 & 8 \\
\hline $\begin{array}{l}9 \\
\text { W5O11 }\end{array}$ & $\begin{array}{l}\text { defining the joint research projects with universities and } \\
\text { research centers, to strengthen the company's internal } \\
\text { capabilities }\end{array}$ & 8 & 7 & 9 & 7 & 9 & 8 \\
\hline $\begin{array}{ll}10 \\
\mathrm{~W} 6 \mathrm{O} 12\end{array}$ & $\begin{array}{l}\text { Company management stability policies to take a greater } \\
\text { share of the domestic market }\end{array}$ & 7 & 7 & 7 & 5 & 6 & 6 \\
\hline $\begin{array}{l}11 \\
\mathrm{~W} 7 \mathrm{O} 13,14\end{array}$ & $\begin{array}{l}\text { To use all the features of advertising to help sales } \\
\text { engineering offices in order to expand the domestic market } \\
\text { share. }\end{array}$ & 10 & 8 & 8 & 8 & 8 & 7 \\
\hline
\end{tabular}

Table 4: Weighted index strategies

\begin{tabular}{lcccccc}
\hline Indicator title & Long term goals & acceptability & possibility & Cost and profit & Compliance with law & simplicity \\
\hline criteria weight & 0.20 & 0.18 & 0.18 & 0.14 & 0.18 & 0.12 \\
\hline
\end{tabular}

Table 5: The final results associated with ranking conservative strategies by TOPSIS method

\begin{tabular}{llll}
\hline Obtained rank & $\mathrm{CL}_{\mathrm{i}}{ }^{*}$ & The relative closeness to the ideal solution & Strategy number \\
\hline 1 & $\mathrm{CL}_{8}{ }^{*}$ & 0.8600 & 8 \\
\hline 2 & $\mathrm{CL}_{7}{ }^{*}$ & 0.7285 & 7 \\
\hline 3 & $\mathrm{CL}_{11}{ }^{*}$ & 0.7203 & 3 \\
\hline 4 & $\mathrm{CL}_{3}{ }^{*}$ & 0.6951 & 4 \\
\hline 5 & $\mathrm{CL}_{4}{ }^{*}$ & 0.6340 & 6 \\
\hline 6 & $\mathrm{CL}_{6}{ }^{*}$ & 0.6301 & 9 \\
\hline 7 & $\mathrm{CL}_{9}{ }^{*}$ & 0.6238 & 2 \\
\hline 8 & $\mathrm{CL}_{2}{ }^{*}$ & 0.5877 & 5 \\
\hline 10 & $\mathrm{CL}_{5}{ }^{*}$ & 0.5644 & 1 \\
\hline 11 & $\mathrm{CL}_{1}{ }^{*}$ & 0.4503 & 10 \\
\hline
\end{tabular}




\section{Conclusion}

The achievement of strategies goals is one of the objectives of many organizations (Nikraftar, 2016). The dynamics of today's environment make necessary planning based on flexible patterns. Therefore, organizations should have flexible plan to achieve their goals in line with the values, vision and mission. In this regard, strategic planning as a useful tool that will assist managers and decision-makers to program implementation (Hajipour et al., 2017). One of the most important tools used by strategic planning is SWOT analysis, which examines the strengths, weaknesses, threats and opportunities of environment, As a result, by use of it and identifying the relevant areas, appropriate strategies is recommended. The important point is that, organizations and companies can choose what strategy, strategies and solutions and approaches to convert the inner weakness to strength, and environmental opportunities to threats. And by utilizing the internal capabilities and environmental opportunities, give their missions objectivity (Kazemi, Shokouhyar, \& Zulfaghari, 2015).

In the present study, a strategy was prepared for IRANOL Oil Company by using quantitative methods. The approach used in this study, provide a strong and good frame for the enthusiasts of management science. In fact, by this model, we can also acquire sufficient discretion on the organization situation and position, and benefit the accuracy of quantitative methods in decision making and strategy formulation, (Shojaei \& Siyahpoush, 2012).

The results showed that the company's position based on the matrix SWOT, is in WO place that is more conservative strategies. Then, according to TOPSIS method, 11 strategies contained in this position, were taken into account in order to evaluation and priority that the results in order of priority are including: Strengthening of $R \& D$, development and implementation of a comprehensive marketing strategy with appropriate ancillary services by development of sales engineering offices, the use of all advertising possibilities, expanding the company laboratories and technologies to reduce purchasing raw material, Increasing the variety of product portfolio for new model vehicles, improving after-sales service, defining the joint research projects with universities and research centers in order to strengthen the company's internal capabilities, expanding base oil export and final product, precise control of the maintenance process and repairs based on regular program, increasing the conversion of base oil to the final product according to the company's internal development capacities and ultimately adoption of the Company management stability policies.

So, according to the obtained results, it is suggested that IRANOL Company based on its budget and plans should give the first priority to the strengthening of R\&D by using of current domestic specialized personnel or attract skilled labor and define improvement projects out of the company. Also, reinforce the internal and external units to improve their marketing and sales, and with special attention to the overall marketing strategies they will take steps in the direction of increasing its market share.

It is suggested that researchers study and compare other strategies of lubricant companies, too. Also, other techniques such as QSPM, ANP and ... can be used at the evaluation stage. 
At the end, We appreciate Dr Mohammad Reza Shojaei; Assistant Professor of management at Shahid Beheshti University in Tehran, Iran; for helpful commentss on this paper.

\section{References}

Ali Ahmadi, A., Fathallah, M., \& Taj al-Din, I. (2004). A comprehensive approach to strategic management: approaches, paradigms, schools, processes, models, techniques and tools, knowledge production. Tehran: Knowledge Production Publications.

Amani DolatSara, H. (2005). Motor oil knowledge. Tehran: BEHRAN Company Publications.

Bakhtiari, L., Vazir Zanjani, H., \& Becker, S. (2014). Strategic dynamics of industrial lubricants. Journal of Strategic Management Studies, 4(15), 157-176.

Biorani, H., \& Ghofran, A. (2009). Explaining and applying TOPSIS Multi-Criteria Decision model for ranking urban areas in terms of crime and delinquency. Journal detectives second term, 2(8), 131-150.

Bryson, J.M. (2011). Strategic planning for public and nonprofit organizations. Wiley: Jossey-Bass Publications.

Coman, A. \& Ronen, B. (2009). Focused SWOT: diagnosing critical strengths and weaknesses. International Journal of Production Research, 47(20), 5677-5689.

Consumer and manufacturers protection organizations. (2015). Iran Lubricant Industry Report, Retrieved from http://www.cppo.ir

David, F. R. (2011). Strategic management. Pearson College Publications.

Dess, G.G., Lumpkin, G.T., \& Taylor, M. (2004). Strategic Management. Mc Hill Publications.

Ebrahimi, R., \& Tabatabai, A. (2000). The audit strategy. Tehran: Productivity Charter Publications.

Ermida, G. (2014). Strategic decisions of international oil companies: Arctic versus other regions. Energy Strategy Review, 2(3), 265-272.

Garvey, R. (2000). Monitoring grease lubricated systems, lubrication and fluid power. (pp. 25-28). Tom Madding Publishing.

Ghazinoory, SS. (2005). Cleaning products: Concepts, techniques, case studies. Tehran: Khajeh Rashid Publications.

Glaister, K.W., \& Falshaw, J.R. (1999). Strategic planning: still going strong. Long Range Planning,32(1), 107-116.

Goodstein, L.D., Nolan, T.M., \& Pfeiffer, J.M. (1992). Applied strategic planning: A comprehensive guide. San Diego: Pfeiffer and Company.

Gosalia, A. (2014). To sustain ability in the global lubricants industry. Paper presented at the 18th ICIS World Base Oils \& Lubricants Conference. London, Available in http:// www.fuchs.com

Grant, R.M. (2003). Strategic planning in a turbulent environment: evidence from the oil majors. Strategic Management Journal,24(6), 491-517.

Guerras-Martín, L.A., Madhok, A., \& Montoro-Sánchez, A. (2012). The evolution of strategic management research: Recent trends and current directions. Business Research Quarterly,17, 69-76.

HajiNejad, A., Taghizadeh, Z., \& Rahimi, D. (2014). Prioritizing tourism hubs and formulating regional tourism development strategies by using TOPSIS technique and SWOT, Case Study. Journal of Urban Ecology research, $4(7), 33-56$.

Hajipour, B. (2015). An analysis of the successful and unsuccessful organizational strategies. Tehran: Shahid Beheshti University Publications. 
Hajmohammadi, M.R. (2017). Assessment of a lubricant based nanofluid application in a rotary system. Energy Conversion and Management, 146, 78-86.

Hasannuddin, A.K., Wira, J.Y., Sarah, S., Wan Syaidatul Aqma, W.M.N., Abdul Hadi,A.R., Hirofumi, N., ... Azrin, M.A. (2016). Performance, emissions and lubricant oil analysis of diesel engine running on emulsion fuel. Energy Conversion and Management, 117, 548-557.

Haynes, B. (2005). Measuring consumer satisfaction (questionnaire design and adjustment) (Nasrin Jazani, Translator). Tehran: Industrial Management Institute publications.

Hill, C., Jones, G., \& Schilling, M.A. (2014). Strategic management theory. (11th Edition) South-Western College Publications.

Jiang, Q., Xu, Y., \& Xin, W. (2012). SWOT-AHP hybrid model for vehicle lubricants from CNPCLC, China. Petroleum Science. 9(4), 558-564.

Kazemi, S.A., Shokouhyar, S., \& Zulfaghari, H. (2015). Macro strategy at central Bank of the Islamic Republic of Iran based on the 2025 outlook. Journal of Strategic Management Studies, 22, 15-38.

Mahmoudi, M., Surrey, M., \& Muhammad Ali Tajrish, I. (2014). Strategic management in oil industries, gas, refining and petrochemicals. Tehran: Mahkame Publications.

Mehregan, MR., \& Dehghan nayeri, M. (2009). An integrated BSC-TOPSIS approach to evaluate the best's Iranian business schools. Journal Industrial Management,1(2), 153 - 168.

Mintzberg, H. (1994). The fall and rise of strategic planning. Harvard Business Review. Retrieved from https://hbr.org/1994/01/the-fall-and-rise-of-strategic-planning

Mohammadpour, M. (2016). Formulating investment strategies in the upstream sector of the oil industry in Iran. Retrieved from http://www.rayeneh.com

Momeni, M. (2006). New topics of research in operations. Tehran: Tehran University Publications.

Nikraftar, T. (2016). Analyzing divergent perspective about strategic direction in the Export Development Bank of Iran (EDBI): Research based on Q-methodology. Iranian Journal of Management Studies, 9(2), 265 - 286.

Panda, J.N., Jayashree, B., \& Pandey, R.K. (2017). Comparative potential assessment of solid lubricants on the performance of poly aryl ether ketone (PAEK) composites. Wear, 384-385, 192-202.

Pearce, R. (2004). Strategic Managemen. Mc Hill Publications.

Phadermrod, B., Crowder, R.M., \& Wills, G.B. (2016). Importance-Performance analysis based SWOT analysis. International Journal of Information Management, In Press.

Prezelj, I. (2015). Improving inter-organizational cooperation in counterterrorism: Based on a quantitative SWOT assessment. Public Management, 17(2), 209-235.

Ramírez-Cendrero, J.M., \& Paz, M.J. (2017). Oil fiscal regimes and national oil companies: A comparison between Pemex and Petrobras. Energy Policy,101, 473-483.

Ravandi, E.G., Nezamabadi-Pour, H., Monfared, A.E.F., \& Jaafarpour, A.M. (2014). Reservoir characterization by a combination of fuzzy logic and genetic algorithm. Petroleum Science and Technology,32(7), 840-847.

Report on China Lubricating Oil Market. (2011-2015). Retrieved from http:// www.ocn.com

Saaty, S., Hatami marbini, A., \& Nakoie, A. (2007). Group decision-making help fuzzy topsis. Journal of Applied Mathematics,4(13), $21-34$. 
Safaye, M. (2013). To identify and prioritize critical success factors in the Iran lubricants industry by using ANP (with the competitive advantage approach). (Business Administration Master's thesis). University of Ershad, Tehran.

Shahidipour, R. (2005). A comprehensive book of Iran lubricant industry. Tehran: Scholar's Market Innovative Company Publications.

Shekarriz, M., Haji Ali Akbari, F., \& EbrahimPour rezaye, E. (2014). Production of nickel-coated nanoparticles and their applications in lubricants. oil research, 80, 54-62.

Sheng-Hshiung, T. (2002). The evaluation of airline service quality by fuzzy MCDM. Tourism Management, 23, 107115.

Shojaei, M. (2015). Strategic planning. Tehran: Shahid Beheshti University of Tehran.

Shojaei, M., \& Siyahpoush, M. (2011). Strategy formulation for Gohar Shafa Medical Equipment Company with Quantitative Strategic Planning Matrix (QSPM). Development and Management process, 24(75).

Stacey, R.D. (2003). Strategic management and organizational dynamics (Mohammad Reza Shojaei, Translator). Tehran: Department of Economic Affairs.

Tavana, M., Pirdashti, M., Kennedy, D.T., Belaud, J.P., \& Behzadian, M. (2012). A hybrid Delphi-SWOT paradigm for oil and gas pipeline strategic planning in Caspian Sea basin. Energy Policy,14, 345-360.

Hajipour, B., Motameni, A., Tayebi Abolhasani, A. (2017). Meta-synthesis of success factors for commercialize of products with advanced technology. Innovation Management Journal, 5(4), 19-54.

Tayebi Abolhasani, A., Rouhani Rad, S., \& Tahouryan, A. (2015). A Study of the export management of Iranian lubricant industry and the environmental factors influencing it. Paper presented at the International Conference on management, Economics and Humanities, Turkey.

Velez-Langs, O. (2005). Genetic algorithms in oil industry: An overview. Journal of Petroleum Science and Engineering, 47(1-2), 15-22.

Yadghar, A., \& Tadayon tahmasebi, M. (2007). Marketing strategic management in oil, gas and petrochemical industry case study: marketing strategic planning model in GC companies in Iran. Paper presented at the first International Conference on Marketing Management, Tehran. 